\title{
Forebyggelse af radikalisering, miskendelse og muslimsk minoritetsidentitet ${ }^{1}$ af Lasse Lindekilde
}

\begin{abstract}
.
Radikale muslimer udgør en meget lille minoritet i minoriteten i Danmark. Ikke desto mindre er der stor politisk bevågenhed omkring fænomenet radikalisering, og en række tiltag er iværksat for at forebygge radikalisering - tiltag som kan synes rettet mod specielt unge muslimer. En præmis for mange præventive tiltag mod radikalisering, herunder mange af tiltagene i regeringens handlingsplan på området fra januar 2009 er, at radikalisering ofte er et produkt af oplevet miskendelse fra det omgivende samfund. Derfor sigter flere af tiltagene, som f.eks. antidiskriminationskampagner, øget medinddragelse, rollemodeller, dialogaktiviteter m.m., mod at forebygge radikalisering ved at mindske vækstgrundlaget i form af oplevet krænkelse. Denne artikel spørger, om nogle af disse tiltag via deres formulering, politiske præsentation og implementering kan være med til at forstærke, snarere end inddæmme oplevelser af manglende anerkendelse hos modtagergruppen. Sagt på en anden måde, så undersøger artiklen, teoretisk såvel som empirisk, holdbarheden af nogle af de antagelser om forandring, som ligger bag den forebyggende indsats mod radikalisering. Artiklen behandler disse spørgsmål ud fra teoretiske betragtninger om forholdet mellem miskendelse, protestadfærd og (radikal) identitetskonstruktion. Det empiriske materiale, som artiklen bygger på, stammer fra en større interviewundersøgelse foretaget blandt unge muslimer i Århus. Artiklen argumenterer for, at en stor gruppe af de unge muslimer i interviewundersøgelsen opfatter den forebyggende indsats mod radikalisering som udtryk for generaliserende miskendelse og mistænkeliggørelse af muslimer, og der derfor eksisterer en fare for, at tiltagene, imod hensigten, kan føre til øget mistillid, afstand og oppositionelle identiteter.
\end{abstract}

\section{Indledning}

Radikale muslimer må anses for at være en meget lille minoritet i minoriteten i Danmark. Ikke desto mindre er der stor politisk bevågenhed omkring fænomenet radikalisering, og en række tiltag er iværksat for at imødekomme radikalisering blandt specielt unge muslimer. Således barslede regeringen i januar 2009 med en handlingsplan om forebyggelse af ekstremistiske holdninger og radikalisering blandt unge under navnet "En fælles og tryg fremtid" (Regeringen 2009). På lokalt plan er der ligeledes taget en række initiativer i samarbejde mellem kommuner og politi, eksempelvis i Århus og senest København. Regeringens handlingsplan indeholder 22 initiativer, som skal forebygge radikalisering blandt unge - ikke bare blandt unge muslimer, men også eksempelvis på den politiske højre- og venstrefløj. Der er dog næppe nogen tvivl om, at unge muslimer har været den primære referencegruppe for formuleringen af initiativerne. Handlingsplanens tiltag er mangfoldige og vidtrækkende. En gruppe af initiativer sigter mod at opstille alternativer til radikale ideologier ved at styrke eksempelvis demokrati- og medborgerskabsundervisning, rollemodeller og mentorkorps samt ved at give konkrete unge jobtilbud eller lærepladser. Andre tiltag sigter mod at besværliggøre rekrutteringen til radikale grupper via præventive samtaler, intensiveret opmærksomhed på problemet i samarbejdet mellem skole, socialforvaltning og politi, kontakter til lokale ungdomsklubber, beboer- og sportsforeninger samt godkendelsesordninger for religiøse forkyndere i fængsler. En betydelig del af initiativerne sigter mod at erodere vækstgrundlaget for radikalisering ved at imødegå krænkelseserfaringer 
blandt udsatte grupper via antidiskriminationskampagner og forskellige former for positiv anerkendelse som f.eks. borgerinddragelse og dialogaktiviteter.

Regeringens handlingsplan bygger, ligesom megen forskning om radikalisering, på en præmis om, at radikalisering kan forklares som et produkt af udbud og efterspørgsel efter radikale ideologier i samfundet. ${ }^{2}$ På den ene side findes der nogle radikale entreprenører, som tilbyder radikale synspunkter, og som aktivt forsøger at hverve medlemmer til radikale grupper, og på den anden side findes der utilpassede unge, som dels afviser, dels bliver afvist af det etablerede samfund, og som derfor søger mod alternative fællesskaber. Den officielle præventive indsats mod radikalisering er designet til at svække både udbuddet og efterspørgslen efter radikale ideologier. Denne artikel spørger, om nogle af disse tiltag ad omveje kan være med til at gøre problemerne med radikalisering større. Mere præcist er det artiklens formål at undersøge, om formuleringen, præsentationen og implementeringen af præventive tiltag i forhold til radikalisering kan være med til at forstærke, snarere end inddæmme oplevelser af at blive afvist og miskendt af det etablerede samfund blandt unge muslimer? Sagt på en anden måde, så forsøger artiklen at undersøge holdbarheden af nogle af de antagelser, som præger "forandringsteorierne", der ligger bag den præventive indsats mod radikalisering, eksempelvis at øget fokus på radikalisering og dens årsager blandt kommunes frontarbejdere fører til øget tillid, oplevelse af inklusion og fællesskab blandt unge i "modtagergruppen. Artiklen peger på, at de unge muslimer i interviewundersøgelsen opfatter den forebyggende indsats mod radikalisering forskelligt, men at den største gruppe betragter initiativerne med skepsis, og hele eller dele af indsatsen som udtryk for generaliserende miskendelse og mistænkeliggørelse af muslimer, der indirekte kan føre til øget mistillid og afstand og mere oppositionelle identiteter. Det konkluderes, at den præventive indsats mod radikalisering ofte fortolkes af de unge muslimer i vores undersøgelse som led i en mere vidtrækkende hetz mod og problematisering af muslimer i Danmark, og at de velmente intentioner bag mange af tiltagene derfor ikke genkendes, og at effekterne dermed er i fare for at blive modsat de intenderede.

Artiklens undersøgelse udspringer af en bekymring, som findes i den akademiske litteratur om antiterrorlovgivning og deradikalisering samt blandt visse politikere om, at sådanne politikker kan have negative, utilsigtede konsekvenser. Ikke desto mindre er dette en mulighed, som er meget ringe udforsket. Teoretisk er artiklens undersøgelse drevet frem af specielt tre strenge af litteratur og indsigter. For det første har normativ politisk teori de senere år stillet skarpt på forholdet mellem 
anerkendelse og identitetsdannelse, og på hvordan anerkendelse i det moderne samfund kan udeblive. Teoretikere som Axel Honneth og Charles Taylor har argumenteret for vigtigheden af anerkendelse fra ens omgivelser for at kunne udvikle ens sande jeg og potentiale. Når anerkendelsen udebliver, kan det have fatale konsekvenser i form af mindreværd og isolation fra samfundet. Det er derfor vigtigt, at man fra politisk hånd, ikke mindst $\mathrm{i}$ multikulturelle samfund, bestræber sig på at udvise lige anerkendelse af alle grupper i samfundet. Dette perspektiv kan være med til at sætte fokus på, hvordan eventuel miskendelse indeholdt $\mathrm{i}$ den præventive indsats mod radikalisering kan påvirke "målgruppens" selvforståelse og identitetsdannelse i negativ retning. For det andet har mere empirisk orienteret forskning $i$ forhold til sociale bevægelser og radikaliseringsprocesser understreget, hvordan politiske tiltag eller konkret indgriben i politiske konflikter, som opleves som diskriminerende eller ubalancerede, kan være med til at fremme "radikal" mobilisering og identitetsdannelse (Gunning 2009, Wiktorowicz 2005, Davenport 2005). Disse indsigter kan bidrage til at belyse muligheden for, at den politiske forebyggelse af radikalisering kan bidrage til, at unge muslimer vender det etablerede majoritetssamfund ryggen og i stedet identificerer sig med radikale, oppositionelle grupper. For det tredje har religionssociologisk forskning i islam i Vesten påpeget en række identitetsmæssige strategier, som benyttes af muslimske immigranter og efterkommere i forhold til det at etablere sig som minoritet, ofte under konditioner af manglende anerkendelse fra majoritetssamfundene (Schiffauer 2007, Maréchal 2003, Bæk Simonsen 2000). Disse strategier forholder sig forskelligt til spørgsmålet om, hvordan anerkendelse skal opnås, og forskningen kan i nærværende undersøgelse bidrage med en opmærksomhed på mangfoldigheden af identitetsmæssige strategier blandt muslimer i Vesten. Den samlede analytiske ramme for artiklens undersøgelse udfoldes i næste afsnit.

Metodisk udspringer artiklens undersøgelse af et eksempel på det, man kan kalde "responsiv sociologi" (Hvid Jacobsen og Kristiansen 1999:9), dvs. sociologisk forskning som er afledt af spørgsmål, der optager den offentlige debat. Hensigten med responsiv sociologi er at forsøge at kvalificere den offentlige debat om bestemte aktuelle emner ved at få de pågældende "målgrupper" i tale og videreformidle og analysere deres betragtninger om emnet. Et bagvedliggende motiv er selvfølgelig også at gøre opmærksom på eventuelle faldgruber i den måde et givet problem gribes an politisk. Mere konkret så bygger artiklen på en større interviewundersøgelse og feltarbejde, som blev gennemført i foråret og sommeren 2009 blandt unge muslimer i Århus, om opfattelser og erfaringer med radikalisering og lokale og nationale handlingsplaner til forebyggelse af 
radikalisering. ${ }^{3}$ Datamaterialet, som artiklen bygger på, består af 39 interviews med 45 individer, heriblandt 18 interviews med unge muslimer, otte med imamer og andre islamiske lærde, samt 13 interviews med relevante "frontarbejdere" såsom skolelærere, klubarbejdere, gadearbejdere, integrationsmedarbejdere m.m. (hvoraf syv var muslimer), som arbejder tæt på unge muslimer i Århus. Desuden er der foretaget gentagne deltagerobservationer ved en række islamstudiekredse, både privat og i moskeer eller muslimske organisationer samt ved forskellige åbne arrangementer om islam i lokalområdet. De unge muslimer, som blev interviewet, tilhører et segment af aktive muslimer i Århus man kan kalde det "arabisk-somaliske konvertitmiljø". Årsagerne til denne udvælgelse har været, at det er i dette miljø, 1) man i Århus finder den mest udbredte islamiske aktivisme, 2) hvor en islamisk vækkelse er mest iøjnefaldende, 3) hvor flest unge orienterer sig imod neo-ortodokse fortolkninger af islam, og 4) hvor "radikale holdninger" ifølge flere kilder uden for miljøet florerer. Der er altså tale om et segment af den muslimske ungdom i Århus, som er meget engageret i forhold til sin religion, og som på mange måder modsvarer det segment, som forskere og myndigheder har i tankerne, retmæssigt eller ej, når de bekymrer sig om radikalisering blandt unge muslimer i Vesten.

Analysen af disse data sigter imod at kortlægge interviewpersonernes opfattelser af den officielle indsats mod radikalisering og ikke mindst interviewpersonernes vurdering af effekter blandt unge muslimer i Århus. Derved søges svar på i hvilket omfang den forebyggende indsats mod radikalisering opfattes som krænkende miskendelse og kan tænkes at være medvirkende til, at unge muslimer vender sig mod oppositionelle identiteter snarere end mod majoritetssamfundet. Da fokuseret forebyggelse af radikalisering er et nyt fænomen i Danmark, og de forskellige programmer og handlingsplaner stadig er under implementering, er der ikke tale om et egentligt policy-effektstudie. Det ville kræve yderligere undersøgelser på et senere tidspunkt. Nærværende data giver altså ikke mulighed for at vurdere direkte om den forebyggende indsats mod radikalisering vil føre til øget radikalisering. Det, som denne artikel kan bidrage med, er unge århusianske muslimers egne opfattelser af og refleksioner over potentielle effekter af præventive indsatser over for radikalisering i forhold til identitetsdannelsesprocesser. I lyset af den betydning som målgruppens perceptioner/modtagelse af policy-tiltag tillægges for realiseringen af effekter i eksisterende politologisk forskning (se fx Winter \& Lehman Nielsen 2008, Winter 2005), vurderes interviewpersonernes egne refleksioner herover at være et interessant sted at starte en diskussion af potentielle effekter af den forebyggende indsats mod radikalisering. Således er det ikke artiklens 
hensigt at bevise eller afvise, at der findes en kausal sammenhæng mellem forebyggelse af radikalisering og radikal identitetsdannelse, men snarere at vurdere, teoretisk og empirisk, holdbarheden af nogle af de antagelser om virkninger/forandringer som ligger til grund for forebyggelsesindsatsen, samt herved påpege mulige faldgruber og mekanismer for kontraproduktive effekter.

\section{Analytisk ramme: Miskendelse og radikal identitetsdannelse}

Som nævnt synes specielt tre strenge af akademisk litteratur at være relevant for en undersøgelse af relationen mellem oplevelser af miskendelse afledt af politiske initiativer eller indgreb og så forskellige former for oppositionel identitetsdannelse. For det første har en række teoretikere inden for normativ politisk teori, heriblandt Axel Honneth, Charles Taylor, Nancy Fraser og Michael Walzer, deltaget $\mathrm{i}$ en lang debat om betydningen af anerkendelse $\mathrm{i}$ moderne samfund. Udgangspunktet for denne debat er, at identitet i en moderne optik er noget, som skabes og forhandles socialt, og ikke længere noget som er afledt af sociale hierarkier. Anerkendelse af ens identitet og dens værdi, både individuelt og kollektivt, er altså noget, som kan udeblive, og som kan nægtes af det omgivende samfund. Anerkendelse anses for at være en forudsætning for friheden til at være sig selv, personlig integritet og det gode liv. Ifølge Taylor er anerkendelse "not just a courtesy we owe people. It is a vital human need' (Taylor 1994:26). Honneth peger på, at anerkendelse/miskendelse af ens identitet og værdi udtrykkes og forhandles i tre forskellige sfærer: den private sfære, som kommer til udtryk i forholdet til familie og venner, den retslige sfære, der omhandler individets juridiske rettigheder, og endelig den solidariske sfære, der knytter sig til de fællesskaber (f.eks. politiske, etniske, religiøse), som individet indgår i (Honneth 2005:93). Anerkendelse i den solidariske sfære, som er den form for anerkendelse, som knytter sig mest direkte an til forholdet mellem minoritet og majoritet, er betinget af, at individet vurderes at bidrage med noget værdifuldt til samfundet og dets reproduktion. Hvad, som anses for værdifuldt, bestemmes af den dominerende kulturelle selvforståelse i samfundet. For at kunne realisere sig selv i et moderne pluralistisk samfund er det derfor ikke tilstrækkeligt at føle sig respekteret inden for en minoritetsgruppe, men derimod i samfundet som sådan (Anderson 2005:xvii). Taylor beskriver konsekvenserne af manglende samfundsmæssig anerkendelse på følgende vis:

Vores identitet formes til dels gennem anerkendelse eller dens fravær - ofte i form af andres manglende anerkendelse af os - hvorfor et individ eller en gruppe af individer kan tage 
alvorlig skade, udsættes for en alvorlig forvrængning, hvis menneskene i det omgivende samfund tilbagekaster et indsnævrende, fornedrende eller ringeagtende spejlbillede af disse individer eller denne gruppe. Ikke-anerkendelse eller miskendelse kan resultere i lidelse og være en form for undertrykkelse, der spærrer nogle mennesker inde i en falsk, forvrænget og reduceret eksistensmodus (Taylor 1994:15. Forfatterens egen oversættelse)

Krænkelser i solidaritetssfæren i form af oplevede fornærmelser, nedværdigelse eller manglende tiltro, indeholdt i f.eks. formuleringen, implementeringen eller den mundtlige præsentation af politiske tiltag, skader den enkeltes selvværd og kan efterlade et psykisk tomrum i individets personlighed. Løsningen for både Honneth og Taylor er "anerkendelsens politik", som skal skabe rammerne for mangfoldighed og værditilskrivning til mange forskellige former for identiteter i pluralistiske samfund. De praktiske implikationer af anerkendelsens politik har været stærkt debatterede og strækker sig fra politisk bevarelse af kulturelle særpræg og tildeling af særlige grupperettigheder til forskellige former for politiske erklæringer, taler og præemblemer, som mere symbolsk udtrykker anerkendelse af minoritetsidentiteter og deres samfundsmæssige værdi.

Spørgsmålet om, hvilke reaktioner som krænkelseserfaringer kan medføre, er noget, som de normative politiske teoretikere har gjort mindre ud af, men Honneth understreger, at tabet af selvværd kun kan repareres via aktiv handling, eksempelvis i form af protest og fornyet kamp for anerkendelse i samfundet eller i form af søgen efter anerkendelse i andre fællesskaber (Honneth 2006:181). Honneth antyder således, at der kan være en sammenhæng mellem politisk modstand, herunder radikal politisk modstand, og krænkelseserfaringer. Men for at få bedre greb om samspillet mellem miskendelse/krænkelse og politisk mobilisering, protest og radikalisering kan man med fordel skæve til en anden og mere empirisk orienteret forskning i forhold til sociale bevægelser og radikaliseringsprocesser. Der findes således en lang række studier af sociale bevægelser, hvis grundlæggende ærinde har været en kamp om anerkendelse af forskellige gruppers værdi og ligeværdighed. Eksempelvis kan nævnes den amerikanske borgerrettighedsbevægelse, kvindebevægelserne og forskellige aboriginerbevægelser. Studierne viser, hvordan miskendelse udløser kollektiv mobilisering og en dyrkelse af negativt valøriserede identiteter for derigennem at søge og erobre anerkendelse. Undertrykkelse af sådanne og andre former for protester har endvidere ofte vist sig at virke mod hensigten, idet f.eks. voldelig repression har ledt til øgede protester, fornyet engagement og mobilisering (se Davenport et al. 2005). Studier af radikaliseringsprocesser 
har påvist en sammenhæng mellem voldelig repression og radikalisering på den måde, at personlige oplevelser af urimelig og uforholdsvis magtudøvelse fra statens side ofte er blevet fremhævet af individer, som har deltaget i voldelige politiske organisationer, som en vigtig årsag til deres accept af brugen af vold (Della Porta 1995). Men radikaliseringslitteraturen peger også på, at krænkelseserfaringer mere bredt, ofte i form af oplevet nedværdigelse og diskrimination, er en del af vækstgrundlaget for radikalisering. Den individuelle eller kollektive afvisning af en bestemt gruppes værdi kan udløse en såkaldt "kognitiv åbning" hos den enkelte, som medfører et vendepunkt og en nyorientering i vedkomnes liv. Denne søgen kan gå i mange retninger, de fleste i ikke-radikale retninger, men nogle kan på baggrund af oplevede krænkelser fra f.eks. majoritetssamfundets side føle sig tiltrukket af radikale grupper, som tilbyder et værdifællesskab, som er defineret i modsætning til det omkringliggende samfund (Wiktorowicz 2005). I radikale grupper kan marginaliserede og miskendte identiteter genvinde anerkendelse og selvværd samtidig med, at man aktivt miskender og krænker majoritetssamfundets normer og værdier, eksempelvis gennem brugen af vold.

Ser vi slutteligt nærmere på forskningen om islam og muslimer i Europa i en anerkendelsesoptik, så kan der udpeges nogle overordnede reaktions- eller identitetsstrategier i forhold til det at etablere sig som minoritet under konditioner af manglende anerkendelse fra majoritetssamfundene. Werner Schiffauer antyder således fire mulige identitetsmæssige strategier blandt muslimske immigranter i Vesteuropa, som forholder sig forskelligt til oplevelser af miskendelse (Schiffauer 2007). Den første strategi er kendetegnet ved, at man indoptager negative perceptioner af eget værd, som reflekteres fra majoritetssamfundet. Resultatet bliver, at man opgiver håbet om anerkendelse fra omgivelserne, isolerer sig fra samfundet og vender blikket indad og udad mod oprindelseslandet. I denne situation søges identitetsmæssig autenticitet hovedsageligt i forhold til ens etnokulturelle oprindelse. Den anden strategi går den modsatte vej og sigter mod at opnå anerkendelse fra majoritetssamfundet ved at nedtone ens religion og etnokulturelle tilhørsforhold. Med andre ord stræber man efter assimilation og den anerkendelse, som kan udløses af det omkringliggende samfunds genkendelse. Her anses identitetsmæssig fuldkommenhed kun som mulig, hvis man skræller visse elementer af sit jeg. Den tredje strategi modsætter sig et sådant assimilationspres uden at isolere sig, men ved at indgå aktivt i en politisk kamp om anerkendelse af islam og ens ret til forskellighed. Denne strategi ses f.eks. i kampen for anerkendelse af synlige islamiske symboler i offentligheden. Ens muslimske identitet bliver her delvist et politisk statement, og mobilisering en strategi for opnåelse af 
anerkendelse. Endelig, for det fjerde, foreligger den mulighed, som også er antydet ovenfor, at man reagerer på miskendelse med vrede, og at man definerer sig selv i direkte opposition til majoritetssamfundet. For nogle betyder dette, at identitetsmæssig autenticitet kun kan findes i islam i dens rene form, som defineres som modsætningen til majoritetssamfundets moralske orden. For nogle ganske få fører disse forhold til en oplevelse af, at man kun kan realisere sig selv og vinde anerkendelse ved aktivt at bekæmpe "krænkeren" i form af det omgivende samfund. I den følgende analyse fokuseres der på, hvorvidt den officielle indsats for forebyggelse af radikalisering kan formodes at virke efter hensigten og modvirke denne sidste form for oppositionelle identitetsdannelse, eller om indsatsen utilsigtet kan være med til at fremme sådanne identitetskonstruktioner.

\section{Forebyggelse af radikalisering som miskendelse?}

I vores interviews med unge muslimer fra det "arabisk-somaliske konvertitmiljø" i Århus, religiøse lærde fra moskeer og organisationer, hvori de unge færdedes, samt relevante frontarbejdere blev interviewpersonerne bedt om at reflektere over den nationale og lokale indsats for forebyggelse af radikalisering. Hensigten var at afdække opfattelser af indsatsen samt vurderinger af dens potentielle effekter. Det kom hurtigt frem, at nogle af de interviewede havde intet eller meget ringe kendskab til disse initiativer. I de situationer oplystes interviewpersonerne om elementerne i regeringens handlingsplan samt indholdet af den lokale indsats i Århus, og interviewpersonerne blev på denne baggrund bedt om at komme med deres umiddelbare reaktioner og vurderinger af indsatsen. En rimelig indvending kunne her være, at man med denne strategi får et biased billede af unge muslimers opfattelser af de forebyggende tiltag, idet man spørger til noget, som ikke fylder i de interviewedes bevidsthed. Dermed afspejler reaktioner ikke reflekterede opfattelser, men snarere generelle opfattelser af den politiske kontekst, som tiltagene er formuleret i. Til dette vil jeg svare, at man ikke kan forvente, at unge muslimer vil sætte sig ned og læse de forskellige handlingsplaner for forebyggelse af radikalisering igennem og på den baggrund danne sig et samlet indtryk af deres hensigtsmæssighed og effekter. I praksis vil langt de fleste unge opnå kendskab til disse tiltag gennem netop indirekte videreformidling enten i medierne eller fra bekendte ${ }^{4}$, og de vil danne deres opfattelse på baggrund af ufuldstændig viden om tiltagene og i samspil med eksisterende opfattelser af dansk politik, minoritets-majoritetsforhold, den offentlige debat om islam i Danmark osv. Hvis man i forlængelse heraf godtager, at forskellige policy-tiltags effekter delvist bestemmes af den måde de afleveres til målgruppen på og af målgruppens vurdering af tiltagenes 
legitimitet/illegitimitet (se f.eks. Winter \& Lehman Nielsen 2008, Winter 2005), så mener jeg, at umiddelbare reaktioner på politiske tiltag indirekte kan give et praj om, hvorvidt tiltagene kan komme til at virke efter hensigten.

På tværs af det indsamlede materiale fra interviews og deltagerobservation kan der identificeres tre hovedpositioner, som varierer med hensyn til opfattelser af den præventive indsats over for radikalisering. Hver position dækker over forskellige opfattelser af konkrete tiltag og deres effekter, som alligevel bindes sammen af fællesartede vurderinger af tiltagenes positive/negative sider samt størrelsen og retningen af deres effekter. Den første position er kendetegnet ved, at radikalisering, og dermed også forebyggelsen af radikalisering, betragtes som uvæsentlig og irrelevant i forhold til interviewpersonernes liv. Interviewpersonerne udtrykker ligegyldighed over for initiativerne, og flere sætter spørgsmålstegn ved nødvendigheden af de nye tiltag. Flere giver udtryk for, at behovet for en aktiv indsats mod radikalisering er stærkt overdrevet fra myndighedernes side, og at radikalisering hovedsageligt er et politisk og akademisk konstrueret problem, som ikke vedkommer dem. Den anden hovedposition betragter indsatsen mod radikalisering i et mere positivt lys, men understreger, at effekterne heraf vil være små. Man anerkender, at der findes en gruppe af unge muslimer i Danmark, som driver i retning af radikalisering, og en aktiv og forebyggende indsats herimod opfattes derfor som både legitim og nødvendig, men man påpeger samtidig, at sådanne processer er meget vanskelige at komme til livs. Fælles for denne opfattelse er, at den forebyggende indsats i forhold til radikalisering anses for at være en form for symptombehandling. Initiativer, som sigter mod vækstgrundlaget for radikalisering, f.eks. antidiskriminationstiltag, samt eksempelvis brugen af præventive samtaler betragtes positivt, men også som utilstrækkelige i kampen mod radikalisering. Den tredje hovedposition ser skeptisk på indsatsen mod radikalisering, som vurderes i lyset af eksisterende forestillinger om, at muslimer i Danmark generelt er genstand for diskrimination, hetz og manglende politisk anerkendelse. Mange opfatter denne indsats som møntet på danske muslimer alene, som et led i en generel mistænkeliggørelse af den muslimske minoritet og en pågående værdikamp mod islam. Interviewpersoner, som udtrykker sådanne opfattelser af den officielle indsats mod radikalisering, påpeger samtidig mulige negative, utilsigtede konsekvenser ved deres implementering. Denne artikel vil i det følgende alene beskæftige sig med denne sidste hovedposition. Det er der flere grunde til. For det første var denne position numerisk set den mest udbredte i vores materiale. Den blev entydigt eller som oftest delvist udtrykt i godt $90 \%$ af interviewene, mens den første hovedposition blev udtrykt i $35 \%$, og den anden hovedposition i 
godt $50 \%$. For det andet er det den sidste position - med dens fremhævelse af mulige negative konsekvenser af implementeringen af nationale og lokale handlingsplaner for forebyggelse af radikalisering - som set fra et samfundsmæssigt og politisk synspunkt - er klart mest bekymrende.

\section{Generalisering som miskendelse}

En udbredt opfattelse i vores interviewmateriale er, at indsatsen mod radikalisering og ekstremisme generaliserer muslimer som problematiske og tilhørende et mistænkeligt segment af samfundet. På trods af handlingsplanernes eksplicitte pointering af, at indsatsen er rettet mod alle former for radikalisering og ekstremisme - på den politisk højre- og venstrefløj såvel som religiøs ekstremisme - oplever mange af vores interviewpersoner, at tiltagene er rettet imod dem. Denne oplevelse bygges primært på en eksisterende opfattelse af en generel stigmatisering af muslimer i den offentlige debat og den politiske diskurs i Danmark samt forestillingen om, at den siddende regering fører en værdikamp mod islam. Med andre ord synes det at være konteksten for implementeringen af tiltagene snarere end den konkrete formulering af tiltagene, som afstedkommer oplevelsen af, at det er muslimer, der er målgruppen for indsatsen. Den forebyggende indsats mod radikalisering formuleres, som alle andre politiske tiltag, ikke i et vakuum, hvilket har betydning for den måde politikken modtages på.

Mere konkret er pointen, at de unge oplever det som udtryk for manglende anerkendelse, når der ikke sondres mellem de ganske få muslimer, som kan siges at være radikaliserede eller i nærheden af at blive det, og så den brede masse af danske muslimer. Der ligger altså i denne optik en miskendelse i fraværet af differentiering og sondring. Et par citater udtrykker oplevelsen:

De unge bliver trætte af den generaliserende afbildning af dem i politik og i medierne. Jeg oplever på nær hånd gennem mit arbejde, at mange af de unge søger mod udlandet og søger arbejde der, fordi de ikke gider høre mere. Det har stået på i årevis, og debatten om radikalisering er bare endnu et lag i denne udvikling. Tilgangen til dette emne har været den samme som til andre emner, der vedrører muslimer og islam i Danmark. Fokus er altid på de ganske få, som har et problem med demokratiet, såsom Hizb ut-Tahrir. Fokus er altid på det negative. Og den brede gruppe af muslimer betaler prisen herfor. Alle de mange unge med muslimsk baggrund, og som er involveret i uddannelsessystemet er gode og fornuftige 
mennesker. Hvad har de med radikalisering at gøre? De bliver trætte af det hele. (Majid 0206-09)

Effekten er, at man bliver træt. Når man generaliserer tingene, bliver alle berørte, også dem som ellers er udenforstående. Det er en meget nedværdigende følelse. Resultatet kan være, at nogen begynder at isolere sig - de går imod det her. (Afif 20-05-09)

Når unge muslimer bliver konfronteret med det her [en præventiv indsats mod radikalisering], så bliver de bekræftet i deres oplevelse af, at de er et problem, at de er mistænkeliggjorte. Denne konfrontation betyder, at de bliver endnu mere bevidste om deres muslimske identitet, da de føler sig trådt på. Dette kan danne grobund for en eller anden negativ reaktion blandt nogen - en tilbagerulning af forståelse. (Ahmed 01-06-09)

Uanset om det er rimeligt eller ej, så kobles den præventive indsats mod radikalisering sammen med en oplevelse af generel mistænkeliggørelse og stigmatisering af muslimer i Danmark. Citaterne udtrykker også forskellige mulige reaktionsstrategier i forhold til den oplevede miskendelse. Det første citat antyder, at nogle unge muslimer vender sig væk fra samfundet og søger anerkendelse udadtil ved simpelthen at forlade Danmark. De to næste citater fremhæver muligheden af en mere oppositionel reaktion, hvor den oplevede miskendelse fører til isolation, søgen efter anerkendelse indadtil og modstand mod det omgivende majoritetssamfund. Ved at den præventive indsats over for radikalisering opfattes som præget af generaliseringer og dermed miskendelse, opstår der en fare for, at tiltagene ikke kommer til at virke efter hensigten. Et andet citat påpeger en yderligere mekanisme, hvorved intentioner og hensigter bag den officielle forebyggelse af radikalisering indirekte modvirkes:

Alle de bløde tiltag i regeringens handlingsplan er gode nok, hvis de bare ikke var fremkommet $\mathrm{i}$ en handlingsplan for forebyggelse af radikalisering. Der er så sandelig et behov for $\emptyset$ get fokus på demokratiske værdier, diskrimination og dialog. Det har vi efterspurgt i årevis. Men når det kommer i denne kontekst, synes jeg, det er problematisk. Hvis jeg var en, som ikke dagligt var i kontakt med unge muslimer, så kunne man opfatte disse tiltag som udtryk for, at man bør holde et vågent øje med alle muslimer. (Naadir 01-06-09) 
Citatet sætter spørgsmålstegn ved den grundlæggende præmis bag indsatsen mod radikalisering, nemlig at man ved at fokusere på problemet og aktivt forsøge at imødegå radikaliseringens vækstgrundlag, kan forøge modtagergruppens oplevelse af tillid og anerkendelse og dermed forebygge radikalisering. Citatet antyder, at velmente "bløde" tiltag, som opleves som havende gode intentioner og formål, vil blive opfattet negativt og ikke virke efter hensigten, når de præsenteres og implementeres som en del af en strategi mod radikalisering. Citatet udtrykker indirekte en overbevisning om, at fraværet af radikalisering er et gode af en karakter, som gør, at det ikke kan opnås ved direkte og fokuseret indsats. Ved at gøre f.eks. dialogaktiviteter eller $\emptyset$ get demokratiundervisning til et middel til at opnå målet "forebyggelse af radikalisering", og ikke et mål i sig selv, opstår der en fare for, at tiltagene ikke kommer til at virke efter hensigten, og dermed at målet fortoner sig i horisonten. Dette synspunkt kan minde om det dilemma, som Jon Elster har beskrevet som "essential byproducts", nemlig det forhold at nogle goder kun lader sig realisere som biprodukter af andre indsatser eller via indirekte strategier (Elster 1983). Uanset om fraværet af radikalisering faktisk er et sådant gode eller ej, så er det værd at bemærke, at flere interviewpersoner også betragter"bløde" tiltag (f.eks. antidiskriminationskampagner) som problematiske og som udtryk for generaliserende miskendelse, når de indgår som middel til at opnå et andet mål, her fravær af radikalisering (se også næste afsnit). Hvorvidt sådanne tiltag vil afstedkomme negative reaktioner i praksis, vil selvfølgelig afhænge af, hvordan tiltagene bliver implementeret og "framet", ja, af om modtager-gruppen er klar over, at de står over for et tiltag, som skal forebygge radikalisering.

Oplevelsen af indsatsen mod radikalisering som generaliserende miskendelse forstærkes i mange interviews af flere forhold. For det første påpeger flere interviewpersoner implicit eller eksplicit, at der i den måde, hvorpå radikalisering bliver defineret af myndighederne, ligger en manglende anerkendelse af vigtige sondringer. Definitionen i regeringens handlingsplan af "ekstremisme" og i forlængelse heraf "radikalisering" lyder således:

Ekstremismen er præget af totalitære og antidemokratiske ideologier, intolerance over for andres synspunkter, fjendebilleder og opdeling i "dem og os". Ekstremistiske idéer kan komme til udtryk på forskellig vis og kan i deres yderste konsekvens medføre, at personer eller grupper anvender voldelige eller udemokratiske metoder for at opnå et bestemt politisk formål, søger at undergrave den demokratiske samfundsorden eller udøver trusler, vold eller 
nedværdigende chikane mod grupper af mennesker på grund af for eksempel deres hudfarve, seksualitet eller tro.

Radikalisering er den proces, hvorved en person gradvis accepterer ekstremismens idéer og metoder og eventuelt tilslutter sig dens organiserede grupper.

Adspurgt om denne definition mener mange interviewpersoner, at den vanskeligt kan skelne mellem religiøs ortodoksi og bestemte politiske sympatier og så ekstremisme, som har til formål at omvælte samfundet, om nødvendigt ved vold. Som eksempler peges der på, at sympati for f.eks. Hamas, som figurerer på internationale terrorlister, kan falde ind under denne definition, ligesom det at tage afstand fra demokratiet, f.eks. ved ikke at stemme ved valg eller ved at ytre sympati for ideen om en sharia-stat, nemt kan tolkes som udtryk for "antidemokratiske ideologier". Herved overses vigtige distinktioner, nemlig at støtten til f.eks. Hamas ses som en støtte til en politisk frihedskamp i en krigslignende situation og ikke som en generel accept af terror, herunder i Vesten, og at ønsket om en sharia-stat er en religiøst begrundet drøm, som man på ingen måder arbejder for i praksis, eller som man forestiller sig vil blive en realitet i Danmark. Pointen er, at disse synspunkter og sympatier, som det er kommet frem i vores interviews, er ganske vidt udbredte blandt unge muslimer, som på ingen måde betragter sig selv som radikale. Mange af vores interviewpersoner udtrykker frustration over, at sådanne synspunkter og sympatier risikerer at blive "genstand for opmarksomhed og bekymring $i$ lyset af officielle definitioner af radikalisering" (Muhammed 24-04-09).

For det andet fremhævede et par interviewpersoner i forhold til den politiske præsentation af handlingsplanen, hvordan de balancerede formuleringer i selve handlingsplanen blev undermineret af den måde, som daværende integrationsminister, Karen Jespersen, omtalte handlingsplanen på. Ved stort set udelukkende at tale om faren for islamisk radikalisering og det på en måde, som gjorde eksempelvis Zubair Butt Hussain ${ }^{5}$ til repræsentant for denne tendens, mente disse interviewpersoner, at ministeren ikke tilbød andre mulige fortolkninger, end at handlingsplanen sigtede til muslimer i en bred forstand. Med andre ord opleves den operationelle definition af kategorien "radikal", som her kommer til udtryk, som generaliserende miskendelse. 
I forlængelse af dette udtrykkes det i flere interviews, for det tredje, at "radikal" er blevet et "klistermærke", som bruges til at dømme folk inde og ude af den offentlige debat: Det bliver en udifferentieret kategori, som anvendes i flæng. De følgende citater eksemplificerer denne opfattelse:

Det er blevet vanskeligere at deltage $\mathrm{i}$ den offentlige debat om integration, og nu om radikalisering. Alt hvad man siger, skal være perfekt afstemt, for at man bliver accepteret. Man skal have de rigtige synspunkter og meninger. Mange tør ikke længere sige deres mening, fordi de er bange for stemplet "radikal". Folk kan ikke udstå at høre os muslimer sige noget, som er i strid med flertallets overbevisning. Hvis man gør det, ses man straks som en, som ikke elsker Danmark, i stedet for en, som bare spørger, om vi ikke kan gøre det lidt bedre. Tidligere havde jeg ikke nogen skrupler ved sige min mening i pressen, nu overvejer jeg det tusinde gange ... Situationen er i dag, at alle de progressive muslimske stemmer i debatten er blevet tavse, hvilket betyder, at stemmer som Hizb ut-Tahrir ikke får nogen kvalificeret modstand (Naadir 01-06-09)

Jeg synes det har været problematisk, fordi det [kategorien "radikal"] har været brugt som klistermærke. Altså tag nu for eksempel Abdul Wahid Pedersen, for nogle år tilbage blev han pludselig stemplet som en eller anden radikal muslim, og nu er der så gået lidt tid, og nu er han en af de moderate ... det kan være, der kommer en tid, hvor han så er radikal igen. Det er sådan et klistermærke, man tager af og på (Taamir 02-06-09)

Konsekvensen af denne udifferentierede brug af termen "radikal" er, som det antydes i citaterne, at mange muslimer enten trækker sig fra den offentlige debat eller undgår at engagere sig af frygt for at blive stigmatiseret som "radikal". Interviewpersonerne oplever, at det er umuligt at udtrykke f.eks. politisk motiveret kritik af USA eller religiøst begrundet forbehold til demokratiet i den offentlige debat uden at blive dømt ude som radikal. En siger således:

Folk må forstå, at muslimske repræsentanter i den offentlige debat må balancere på en knivsæg. Danske muslimer har mange flere virkeligheder og bekymringer end almindelige danskere. De bekymrer sig om udenrigspolitik, problemer i deres oprindelseslande. Mange er kritiske over for USA af politiske grunde. Som repræsentant kan du ikke bare tale ligesom Naser Khader - det reflekterer ikke virkeligheden. Du mister legitimitet. Muslimske 
repræsentanter kan ikke spille en rolle i kampen mod radikalisering på de præmisser, som regeringen og medierne lægger ud. Det er en balance, og disse ressourcepersoner har brug for råderum til at argumentere på deres egen måde uden at blive kaldt radikale (Taamir 02-06-09)

Citatet udtrykker, at der i den måde, som den offentlige debat om islam og muslimer i Danmark, og herunder om radikalisering, foregår på, ligger en manglende anerkendelse af den vanskelige balancegang, som muslimske repræsentanter må udføre. En manglende anerkendelse, som man kan frygte vil føre til tavse stemmer og mindre dialog. Samtidig kan man anføre, at anerkendelsesteoretikerne faktisk er inde på, at demokrati og accepten heraf er en vigtig forudsætning for anerkendelse $\mathrm{i}$ et samfund. Der er med andre ord grænser for, hvilke "udemokratiske" eller "uliberale" identiteter, som skal anerkendes. Spørgsmålet, som ikke skal behandles videre her, er, om man kan kræve af unge muslimer, såvel som andre, at de i holdning tilslutter sig eksempelvis det liberale demokrati, eller alene kræve, at man i handling respekterer demokratiets spilleregler og andres frihedsrettigheder (for en behandling af dette spørgsmål, se Joppke 2008).

Opsummerende kan man sige, at vores interviews viser, at en række forhold ved den officielle indsats til forebyggelse af radikalisering, og den offentlige debat herom, bliver opfattet som udtryk for generaliserende miskendelse af muslimer i Århus. En miskendelse og oplevelse af krænkelse, som udspringer af, at vigtige sondringer tilsløres og udelades i den måde, der tales om radikalisering og forebyggelse på. Det, man kan frygte, og som antydes i flere refererede citater, er, at man ved at sætte fokus på radikalisering via en målrettet, præventiv indsats ad omveje kan lægge til puljen af oplevet miskendelse og diskrimination blandt unge muslimer snarere end at inddæmme sådanne oplevelser. Med andre ord opleves det, at indsatsen mod radikalisering og den offentlige debat herom er med til yderligere at problematisere og mistænkeliggøre den religiøse minoritet muslimer som helhed. Gennem forskellige mekanismer bevirker tiltagene indirekte, at muslimer bekræftes $\mathrm{i}$ at være udenfor - $\mathrm{i}$ at være en minoritet. Det vil sige, at tiltagene kan være med til at styrke minoritetsidentiteten på bekostning af en mere inklusiv selvforståelse. Hvis man anerkender præmissen om, at oplevet miskendelse, diskrimination og krænkelse er nogle af hovedingredienserne i radikaliseringsprocesser, antydes det altså, at disse tiltag kan være med til indirekte at fremme modtageligheden over for radikale synspunkter. 


\section{Konkrete tiltag som miskender}

Hidtil har vi fokuseret på, hvordan indsatsen mod radikalisering i sin helhed opfattes som udtryk for en generaliserede miskendelse af nogle muslimer. Men i flere interviews udtrykkes der endvidere en mere specifik skepsis i forhold til forskellige konkrete tiltag indeholdt i regeringens handlingsplan eller i lokale initiativer på området. Dette er tilfældet eksempelvis i forhold til mentor- og rollemodelordninger. En interviewperson udtrykker det således:

Jeg er så træt af rollemodeller. Det er blevet en hel religion, forstår du. Det, som denne besættelse af rollemodeller egentligt siger, er: "Der er få rollemodeller blandt muslimer i Danmark, men store kriminelle netværk”. Det er ikke rigtigt - det er ikke et sandt billede. Det er i virkeligheden meget diskriminerende. Sandheden er, at der findes mange velfungerende, almindelige, normale mennesker, som går i gymnasiet og på universiteterne. Der er kun få kriminelle. Det er sådan, det er; billedet skal vendes på hovedet. (Racheed 31-03-09)

Det implicitte budskab i rollemodelkampagner anses som udtryk for miskendelse af her unge muslimer, da det antydes, at muslimer har særligt brug for rollemodeller. Denne oplevelse af miskendelse udspringer ikke så meget af generaliseringer, men snare af udpegningen af muslimer som en gruppe med særlige behov. Rollemodeller og mentorordninger er meget udbredte på integrationsområdet i Danmark og har vist sig at være effektive tiltag på specielt uddannelsesområdet og arbejdsmarkedet. Men flere interviewpersoner sætter spørgsmålstegn ved, om disse tiltag kan overføres til det forebyggende arbejde i forhold til radikalisering:

Jeg kan ikke se, hvordan rollemodeller kan virke på radikaliseringsområdet. De virker, når vi taler om uddannelse og arbejde. Men hvem er det, som skal matches her? Kriterierne er meget uklare. Jeg tror, at rollemodeller skal fremkomme på en naturlig måde fra miljøet for at kunne virke efter hensigten. (Muhammed 24-04-09)

Evalueringerne af rollemodelkampagner og mentorprogrammer med hensyn til forebyggelse af radikalisering antyder, at disse tiltag ville kunne give tilbageslag ved at lægge til puljen af oplevet miskendelse fra majoritetssamfundet.

Ifølge mange interviewpersoner er det største problem med handlingsplanerne på nationalt såvel som lokalt plan dog forslaget om at gøre radikalisering til et nyt "bekymringsparameter" i det 
præventive arbejde udført af SSP-folk, socialrådgivere, skolelærere, gadearbejdere og ansatte i ungdomsklubber m.m. De fleste interviewpersoner udtrykte bekymring over, at denne strategi vil skabe mistillid mellem myndigheder og muslimer, og at repræsentanter for offentlige myndigheder vil begynde at se radikalisering, hvor der faktisk ikke er nogen. Et par citater sammenfatter denne opfattelse:

Hvis man bliver bedt om at se efter spøgelser, så vil man helt sikkert også begynde at se dem. Eller man vil i det mindste opdage noget, man synes er mærkeligt. Det er en farlig udvikling, det er lidt STASI-agtigt, hvor alle bliver bedt om at overvåge de fremmede. Specielt i vores samfund, hvor myndighederne er alle steder - i skolen, på socialkontoret, i børnehaven osv. Overvågningen vil blive massiv, og det vil helt sikkert skabe afstand, og det er farligt, mener jeg. (Imran 25-02-09)

Disse initiativer er dømt til at fejle. Forestil dig en socialarbejder, som ikke ved noget om en persons baggrund, og som ikke har noget begreb om, hvad det vil sige at være muslim, og at denne person så bliver bedt om at holde øje med tegn på radikalisering hos en muslimsk person eller familie. Jeg kan ikke i mine vildeste fantasier forestille mig, hvordan denne socialrådgiver skulle kunne udvikle de nødvendige forudsætninger for en sådan bedømmelse via et par kurser. Jeg kan ikke se, hvordan en situation, hvor nogen bliver bedt om at evaluere på andre folks tanker, meninger, tøj og reaktioner, kan medføre noget godt. Effekten vil blive negativ, der vil komme en modreaktion. Der er i forvejen mange muslimer, som mener, at de sociale myndigheder er karakteriseret ved stereotype forestillinger og fordomme. Tilliden er allerede lav. (Afif 20-05-09)

Forslaget om at gøre radikalisering til et nyt "bekymringsparameter" menes at ville producere et lag af mistillid og mistænksomhed mellem muslimer og myndighedsrepræsentanter, som ellers besidder vigtige positioner $\mathrm{i}$ forhold til at hjælpe og guide de unge. Dette vil betyde afstand og modreaktioner. Implicit peger citaterne på, at tiltagene ikke anerkender de unges privatsfære ved at gøre visse synspunkter og fremtoning til genstand for særlig opmærksomhed og bekymring. Citaterne peger også på spørgsmålet om, hvad tegn på radikalisering er - hvad som skal få markarbejdere til at bekymre sig. Selvom dette ikke er defineret i hverken den nationale handlingsplan eller i de lokale Århus-initiativer, så synes en nærliggende praktisk løsning at være, at fokus bliver rettet mod pludselige forandringer i opførsel, fremtoning og holdninger. Det vil sige, 
at fysiske og holdnings-forandringer bliver evalueret som mulige indikatorer på radikalisering. Ifølge mange af de interviewede muslimer i Århus, er faren ved en sådan strategi atter, at religiøs ortodoksi og politisk motiverede sympatier forveksles med radikalisering. Mange af vores interviewpersoner deler den opfattelse, at markarbejdere, som er i kontakt med unge muslimer, ikke kan tilegne sig de nødvendige forudsætninger for at drage denne skillelinje ved at deltage i opmærksomhedskurser.

Det er således en udbredt opfattelse blandt de unge muslimer i vores interviewundersøgelse, at radikalisering ikke kan gøres til et meningsfuldt "bekymringsparameter" på linje med stofmisbrug, kriminalitet eller vanrøgt af børn. Der findes ikke nogen objektive indikatorer for radikalisering, som der gør på disse andre områder. Flere interviewpersoner afviser direkte denne analogi. En interviewperson siger:

Jeg køber ikke det argument, at uddannelse af f.eks. skolelærere i forhold til radikalisering er ligesom andre præventive tiltag. Fordi det her er et meget politisk område, hvor alle har deres meninger. Vi har alle holdninger, det gælder også SSP-folk, de er ikke supermennesker. Man kan også have holdninger $\mathrm{i}$ forhold til stofmisbrugere, men vi har alle en fundamental fornemmelse af, at de har brug for hjælp. Det er noget andet med holdninger til immigranter og muslimer og forestillinger om, at de ikke gør nok for at integrere sig. Disse holdninger er mere vanskelige at skubbe til side og sige, "vi må også hjælpe dem". Det nager mig, at SSP bliver en del af det her arbejde, det kan kun gå galt. (Muhammed 24-04-09)

Logikken i disse udsagn er, at individuelle opfattelser og holdninger til muslimer og islam vil påvirke den måde, hvorpå fysiske tegn vil blive evalueret. Implementeringen af dette nye "bekymringsparameter" anses for at være meget sensitivt i forhold til personlige idiosynkrasier og politisering. Her er ikke tale om sociale problemer, men politik.

\section{Konklusion}

Denne artikel har rejst spørgsmålet, om officielle forebyggende indsatser mod radikalisering kan tænkes ad omveje at føre til krænkelsesoplevelser og oppositionel identitetsdannelse snarere end 
oplevelser af inklusion og dannelse af identiteter, som åbner sig mod majoritetssamfundet. Svaret herpå er ja. Artiklen har påpeget, hvordan interviewpersonernes perceptioner af de forebyggende tiltag mod radikalisering som udtryk for manglende anerkendelse kan føre til oppositionel identitetsdannelse, og dermed øge risikoen for, at tiltagene ikke får de tilsigtede konsekvenser. Det har ikke været artiklens hensigt at bevise eller afvise, at der findes en kausal sammenhæng mellem forebyggelse af radikalisering og radikal identitetsdannelse, men snarere at vurdere, teoretisk og empirisk, holdbarheden af nogle af de antagelser om virkninger/forandringer som ligger til grund for forebyggelsesindsatsen, og herved påpege mulige faldgruber og mekanismer for kontraproduktive effekter.

Det teoretiske fokus for undersøgelsen har været anerkendelse/miskendelse og dens forhold til identitetsdannelse blandt unge muslimer i Vesten. Med udgangspunkt i en større empirisk undersøgelse blandt unge muslimer i Århus har artiklen argumenteret for, at tre hovedpositioner kan identificeres i forhold til, hvordan unge muslimer oplever og vurderer effekterne af præventive indsatser mod radikalisering. Den første position anskuer indsatsen som irrelevant og overflødig, mens den anden position betragter tiltagene mere positivt, men vurderer at effekten vil være lille. Den tredje hovedposition, som har været artiklens fokus, antyder negative, utilsigtede konsekvenser af den måde, hvorpå den forebyggende indsats mod radikalisering formuleres, implementeres og præsenteres politisk. Således har analysen af interviewpersonernes udtalelser om de forebyggende indsatser påpeget, at en række hensigter i f.eks. regeringens handlingsplan undermineres ved, at unge muslimer oplever planen som helhed, eller forskellige specifikke delelementers implementering, som udtryk for miskendelse. En række interviewpersoner beskriver, hvorledes indsatsen mod radikalisering opfattes som rettet mod muslimer generelt, og hvordan væsentlige sondringer og distinktioner, f.eks. mellem religiøs ortodoksi, politiske holdninger og radikalisering, sløres i den måde, hvorpå tiltagene præsenteres politisk, og radikalisering defineres. Tilsvarende opleves det, at der i den manglende anerkendelse af distinktioner mellem på den ene side bestemte politiske sympatier og religiøst motiverede undtagelser (valgdeltagelse eller uforbeholden tilslutning til demokratiske principper) og så på den anden side samfundsomstødende aktivitet, gemmer sig en generaliserende miskendelse af muslimer i Danmark.

Analysen har endvidere antydet, hvordan disse oplevelser af miskendelse indeholdt i den politiske indsats til forebyggelse af radikalisering, dens implementering eller politiske præsentation kan spille 
sammen med identitetsdannelsesprocesser blandt de unge repræsentanter for den muslimske minoritet i vores interviewundersøgelse. Det er således blevet antydet af vores interviewpersoner, i overensstemmelse med eksisterende studier af sociale bevægelser og muslimske identitetsstrategier i Vesteuropa, at manglende anerkendelse kan føre til oppositionel mobilisering og identitetsdannelse. Flere interviewpersoner gav udtryk for, at den præventive indsats mod radikalisering, eksempelvis via ideen om at implementere radikalisering som et nyt bekymringsparameter blandt SSP-medarbejdere, ville føre til større mistillid, mere indadvendthed og modreaktioner blandt unge muslimer. Det er ikke sådan, at analysen peger på, at unge muslimer på grund af den præventive indsats mod radikalisering pludselig vil ændre adfærd eller selvforståelse, men snarere at de negative perceptioner, som tiltagene afføder, kan lægge til en allerede eksisterende pulje af krænkelseserfaringer, der ifølge teorien kan danne grobund for (radikal) oppositionel identitetsdannelse. Mekanismen, som antydes, er, at når det omgivende samfund via politiske tiltag og den offentlige debat tilbagekaster et negativt billede af den kollektive identitet som muslim, og ikke mindst dens interne mangfoldighed, så reagerer nogen med søgen efter anerkendelse i fællesskaber, som aktivt modsætter sig majoritetssamfundet.

Man kan indvende mod de konklusioner, som nærværende artikel fremhæver, at de har en noget spekulativ karakter. Når alt kommer til alt, er der jo ikke tale om andet end nogle få århusianske muslimers opfattelser og vurderinger af potentielle effekter af en politisk indsats, som de med egne ord til tider ved lidt om. Imod denne indvending vil jeg fremføre, for det første, at der ingen grund er til at tro, at perceptioner/modtagelse af policy-tiltag med hensyn til forebyggelse af radikalisering ikke skulle være delvist medbestemmende for tiltagenes effekter, sådan som det har vist sig at være tilfældet på en lang række andre policy-områder. Tværtimod kan man forestille sig, at faren for, at hensigterne bag den præventive indsats mod radikalisering bliver misforstået/afvist, er særlig stor blandt unge muslimer i Danmark, som vil danne deres opfattelse på baggrund af ufuldstændig viden om tiltagene, og i samspil med eksisterende opfattelser af dansk politik, minoritetsmajoritetsforhold, den offentlige debat om islam og muslimer i Danmark. At hensigterne bag den præventive indsats misforstås/afvises fører naturligvis ikke til en 'radikal' reaktion, men potentielt til en oplevelse af miskendelse, som ifølge teorien blandt andet kan føre til oppositionel identitetsdannelse. For det andet, og i forlængelse heraf, mener jeg, at den type umiddelbare reaktioner og vurderinger, som er kommet frem i vores interviews med hensyn til officielle indsatser til forebyggelse af radikalisering, må tages alvorligt som en indikation på, hvordan disse 
tiltag kan blive opfattet og indvirke på lignende miljøer andre steder end i Århus. Endvidere vil min formodning være, at mange af de samme opfattelser af de præventive indsatser, som vi har identificeret med hensyn til det jeg har kaldt det arabiske-somaliske-konvertit miljø i Århus, vil kunne genfindes hos mange andre danske muslimer af forskellig observans. Men det vil selvfølgelig kræve en særskilt undersøgelse at bevise.

På baggrund af det ovenstående mener jeg, at artiklens konklusioner kan give anledning til bekymring. Indsatsen mod radikalisering er et sensitivt område, som påvist nemt kan give anledning til negative fortolkninger af politiske intentioner og hensigter, på trods af bestræbelser på det modsatte. Noget tyder således på, at mulighedsbetingelserne for politikker i Danmark, som sigter direkte mod forebyggelse af radikalisering, og som samtidigt ikke vil blive mødt med en vis modstand blandt mange muslimer, er snævre. Dermed ikke sagt, at man ikke aktivt skal forsøge at forebygge radikalisering, men det sætter ekstra store krav til, ikke kun hvordan tiltag og definitioner formuleres på skrift, men også til hvordan de præsenteres politisk, operationaliseres i offentlige debatter og implementeres lokalt.

\section{Litteratur}

Anderson, Joel, 2005: “Autonomy, Vulnerability, Recognition, and Justice” (co-authored with Axel $\underline{\text { Honneth) }}$ i John Christman \& Joel Anderson (red.), Autonomy and the Challenges to Liberalism: New Essays. New York: Cambridge University Press, 127-49.

Bæk Simonsen, Jørgen, 2000: "From Defensive Silence to Creative Participation: Muslim Discources in Denmark", in: Felice Dassetto, ed., Paroles dislam. Individus, sociétés et discourse dans l"islam européen contemporain, Maisonneuve et Larose, Paris, 145-155.

Gunning, Jeroen, 2009: “Social Movement Theory and the Study of Terrorism”, in R. Jackson, M.

Breen Smyth, J. Gunning Critical Terrorism Studies: Framing a New Research Agenda, London: Routledge.

Davenport, Christian, 2005: "Repression and Mobilization: Insights from Political Science and Sociology", I Christian Davenport, Hank Johnston and Carol Mueller (red.), Repression and Moblization, Protests, and Contention, Minneapolis: University of Minnesota Press.

Della Porta, Donatella, 1995: Social movements, political violence, and the state: a comparative analysis of Italy and Germany. New York: Cambridge University Press. 
Elster, Jon, 1983: Sour Grapes. Cambridge: Cambridge University Press.

Honneth, Axel, 2006: “The Work of Negativity - A psychoanalytical Revision of the Theory of Recognition". Critical Horizons 7 (1): 101-11.

Hvid Jacobsen, Michael \& Søren Kristiansen, 1999: "Hvor farligt er det farlige feltarbejde? En etisk-sociologisk belysning og problematisering af deltagende observation i social afsondrede miljøer " i Sociologiske Arbejdspapire. Aalborg: Aalborg University.

Joppke, C., 2008: "Immigration and the identity of citizenship: The paradox of universalism", Citizenship Studies, Vol. 12, No. 6, pp. 533-46.

Kühle, Lene \& Lasse Lindekilde, 2010: Radicalization among Young Muslims in Aarhus.

Forskningsrapport udarbejdet for Center for forskning i Islamisme og

radikaliseringsprocesser, Århus Universitet.

Maréchal, Brigitte, 2003: “The Question of Belonging”, in Brigitte Maréchal, Stefano Allievi,

Felice Dassetto and Jørgen Nielsen (eds.), Muslims in the Enlarged Europe. Leiden: Brill

Schiffauer, Werner, 2007: "From exile to diaspora: the development of transnational Islam in Europe." I Islam in Europe. Diversity, Identity and Influence, red. Aziz Al-Azmed og Effie Fokas: Cambridge University Press.

Taylor, Charles, 1994: "The Politics of Recognition." I Multiculturalism. Examining the politics of Recognition, red. Amy Gutmann. New Jersey: Princeton University Press.

Wiktorowicz, Quintan, 2005: Radical Islam Rising: Muslim Extremism in the West: Rowan and Littlefield Publishers.

Winter, Søren, 2005: Implementering og effektivitet. København: Academica.

Winter, Søren \& Vibeke Lehman Nielsen, 2008: Implementering af politik. København: Academica.

\footnotetext{
${ }^{1}$ Forfatteren skylder en stor tak til mine kollegaer i afdelingen for sociologi ved Institut for statskundskab, Århus Universitet, samt to anonyme bedømmere for særdeles værdifulde kommentarer til tidligere udkast af denne artikel.

${ }^{2}$ For en problematisering af regeringens definition af radikalisering og bagvedliggende teorier, se Kühle \& Lindekilde 2010.

${ }^{3}$ Undersøgelsen blev foretaget i regi af Center for Forskning i Islamisme og Radikaliseringsprocesser ved Institut for Statskundskab, Aarhus Universitet. Alle interviews er foretaget af forfatteren selv, af lektor i religionsvidenskab, Lene Kühle, eller i fællesskab. Undersøgelsens samlede resultater kan findes i Kühle \& Lindekilde 2010.

${ }^{4}$ Det kan selvfølgelig ikke afvises, at den måde som intervieweren beskriver de politiske tiltag på vil afvige fra, hvordan medierne og de unges bekendte vil gøre det. Tiltagene er i interviewsituationen forsøgt præsenteret så åbent som muligt.

${ }^{5}$ Fremtrædende medlem af den tværetniske forening Muslimer i Dialog samt talsmand for Muslimernes Fællesråd.
} 
Lasse Lindekilde er siden 2009 ansat som adjunkt ved institut for Statskundskab, AU, og uddannet Ph.d. fra det Europæiske Universitets Institut i Firenze på en afhandling om danske muslimers reaktioner på publiceringen af Muhammed-karikaturerne (2008). Lasse har forsket i muslimers forhold som minoritet i Europa, Muslimers politiske deltagelse, mobilisering og senest spørgsmål om radikalisering og radikaliserings-forebyggelse. Herforuden interesserer han sig for bredere spørgsmål om immigration, integration, anerkendelse, religiøs aktivisme, og indvandreres medborgerskab.

\section{English résumé}

Radical Muslims make up a very small segment of the Muslim minority in Denmark. Nevertheless, there has been a large political interest in the phenomenon of radicalization, and several national and local action plans to prevent radicalization have been launched - initiatives which primarily seems to be directed at young Muslims. An underlying premise of most preventive measures against radicalization, including many of the initiatives proposed in the Danish government action plan from January 2009, is that radicalization is a product of experienced misrecognition from the majority society. This is why several of the political initiatives in the field are targeting the base of radicalization through e.g. anti-discrimination policies, role model campaigns, strategies of inclusion and dialogue. This article, however, pose the question of whether or not such political initiatives by way of formulation, presentation and implementation might rather add to the pool of experienced misrecognition among young Muslims than delimit it. Put differently, the article investigates, theoretically and empirically, the soundness of some of the implicit assumptions of change driving preventive strategies against radicalization. The article deals with these questions on the base of theoretical insights on the relationship between recognition, protest behavior and (radical) identity construction. Empirically the article rests on a large interview study conducted among young Muslims in Aarhus, Denmark. The article argues that as a large group of the interviewees perceive the preventive measures against radicalization as showing lack of recognition and stigmatization of (all) Muslims in Denmark, there is a risk that these measures unintentionally can lead to increased mistrust, distance and oppositional identity construction. 